\title{
5 Highway to Hell
}

\section{Transition Grammar}

In a tourist bus with dark windows that goes from here to there, and there to here, people sit and watch what is passing them by outside. Outside, there are other people, and they do not look back. There is no use in looking back; one such bus after another, making some noise and leaving some dust behind, like the wind that blows into the plastic bag heaps from time to time, all day. There is work to do, a road to travel, business to mind.

Not that those in the bus do not also have work to do, a road to travel and business to mind. But in order to do the things they have to do now, they need those passing people outside and their plastic bag heaps and dust and stillness. While the aircon hums, the click of a camera resounds. Click-click-click, and soft voices speak. Faces turned against the darkened glass, eyes pressed against the windows: 'Look here!' A line from a poem by Anne Carson (2016) reads "I suppose and I presume."

It belongs to a poem named 'Sonnet of Exemplary Sentences from the Chapter Pertaining to the Nature of Pronouns in Émile Benveniste's Problems in General Linguistics (Paris, 1966)', which can be found on the page opposite another poem that is called 'Sonnet of the Pronoun Event'.

In the tourist bus with its dark windows and the closeness of faces and glass, the work that people do is that of supposing and presuming. Also the talking: this is another work that should be done on the way to the destination to which they are heading. Pronouns indeed play a role in it, and an eventful role, even. To the linguist, the language of the interior of the tourist bus on the way to its destination is an important field of study, which helps to understand the use and meaning of pronouns in particular, as well as other communicative phenomena such as click sounds.

In the air-conditioned tourist bus with its dark windows, there is some seclusion that shelters those who speak from those who might want to ask. The driver may not even hear what they say, with the aircon humming all 
the time. Like water in a park's refreshing spring, it hides the meanings of the words that are spoken.

In this seclusion, which turns the interior of the tourist bus into a kind of liminal space through which the tourists will have to pass until their destination is reached, a special form of language is used, as is normally the case in liminal spaces. In the tourist bus, this is a language that is used to suppose and presume. Therefore, its vocabulary is a bit reduced; it is a specialized language that fulfils very particular tasks, that is not used to bargain in a market, for example. Verbs in this language form a closed word class, which is typical of some ritual languages, whereas in languages of everyday communication, verbs often form an open word class (Kanuri is among the exceptions here; cf. Dimmendaal, 2006). The verbs that form part of the tourist bus interior register include:

$\begin{array}{lll}\text { (1.a) } & \text { schau! } & \text { 'look.ImP' } \\ & \text { denk! } & \text { 'think.ImP' } \\ & \text { uberleg! } & \text { 'consider.ImP' } \\ \text { sieh! } & \text { 'see.ImP' } \\ \text { (1.b) } & \text { leben } & \text { 'live' } \\ & \text { wohnen } & \text { 'inhabit' } \\ & \text { zurechtkommen } \\ \text { gewohnt sein } & \text { 'get along with' } & \text { 'be used to' }\end{array}$

In Example (1.a), a group of verbs denoting cognition is presented. An interesting feature of the verbs in this category is that they are often used in a truncated form, almost in an iconic fashion. The shortness of the verb parallels the limitations of cognitive experiences in the liminal space inside the tourist bus. Mostly watching what is outside, the people inside experience visual sensations and imagination. Nothing else.

In Example (1.b), some verbs that express stative location and habituation are presented. The verbs of this particular set are hardly ever truncated, which might be another example of iconicity in ritual language: the everlasting state in which those outside seem to be requires long verb forms that provide an almost tangible sensation of continuity.

An interesting feature of the verbs in group (1.b) is that they tend to occur with only one subject pronoun, namely sie/die 'they'. In other words, almost all constructions that pertain to life and existence are constructed in the third-person plural. The outside world viewed from the tourist bus is not perceived as fragmented and diverse, and all contradictions that are part of a life shared by many individuals are erased from 
discourse. The people who can be seen outside are constructed as one large group, a mass, a single collective body.

Unsurprisingly, collective nouns represent another word class that is characteristic of the register of the tourist bus interior:

$\begin{array}{ll}\text { (2) Hiesige } & \text { 'autochthonous people' } \\ \text { Afrikaner } & \text { 'Africans' } \\ \text { Locals } & \text { 'locals' } \\ \text { Leute } & \text { 'people' } \\ \text { Eingeborene } & \text { 'natives' }\end{array}$

Anne Carson's 'Sonnet of the Pronoun Event' ends with by asking whether pronouns are like lilies; she concludes that they indeed are, how else would they constitute events.

Events can happen in unexpected ways, very much to the surprise of their beholders. In some languages, actually many of them, this is encoded by the use of specialized grammatical forms (Aikhenvald, 2004). Often described as a sub-category of evidentials (which largely encode the source of information), miratives express unpredictability and surprise. That miratives and evidentials are often in close relationships with each other is not surprising at all, because evidentials also help to describe the reliability of information, as first-hand information or as something one only knows through hearsay. Miratives express that something has really happened (truth, a particular quality of information) even though it seemed improbable and lily-like.

In the language of the tourist bus interior, miratives abound. They do not form a special class of grammatical formatives, however, but are mostly derived from interjections and (much more rarely) adjectives. As one can expect, they are used to modify verbs that express vision and cognitive processes based on visual sensation. Examples are:
(3) boah kuck
MIR.VIS look.IMP
'surprise: look.IMP'
$\begin{array}{ll}\text { nee } & \text { ne } \\ \text { INTENS } & \text { MIR.VIS }\end{array}$
schauma
'unbelievable: see there.IMP'
hammer glaubstes
MIR.vis believe.2SG.O3sG
'impossible: do you believe this'

The use of mirative constructions is constrained by gender. Female speakers tend to utter them more often and in a more nuanced way, whereas male speakers are reluctant to use miratives extensively. If they do, they usually utter them in a hissing way, with more friction: 
(4) Gendered miratives

(4.1) Female mirative register heyyyy sieh doch nee ey 'improbable: just see.ImP' MIR.VIS look.IMP INTENS INTENS INTENS

(4.2) Male mirative register

ssss nee hassse nich gesehn 'improbable: just see' MIR.VIS INTENS have.2SG NEG see.PAST

In discourse, mirative constructions tend to introduce comparative constructions. Moreover, a characteristic feature of the register of the airconditioned tourist bus is that comparative constructions often merge with locative constructions. We interpret this as another highly iconic function of the register: spoken in a fundamentally transitional, even moving entity, comparisons between different places - here and there, then and now - are of utmost importance. Examples of how the dynamic state of those who speak is represented by language are:

(5) Locative comparative constructions

nee ne glaubstes wie $\mathrm{da}$ in Italien der Basar
INTENS MIR.VIS believe.2sG.03SG COMP LOC LOC Italy DEF market 'Hard to believe that this is like there at the market in Italy!'

boah kuck wie in Pattaya MIR.vis look.IMP COMP LOC Pattaya 'Just look, the same as in Pattaya!'

While toponyms and other proper nouns form an unstable part of the tourist bus register, loan words and neologisms that refer to foreign places and things do not. Dynamicity and transition are embodied and performed in the bus, and this is saliently reflected in language. Words that have origins in other languages are used extensively. They are somewhat isolated as entities, as items worshipped in a cargo cult, and usually do not occur together with other lexical entities of the same origin. In the tourist bus language, solitary words help to stylize and perform otherness and transition. Some examples are:

(6) Dashiki

Kikoi

hakuna ma Vodka

Zungu

Pumpe

\author{
'cotton shirt with African print' \\ 'cotton cloth with African print (kanga)' \\ 'cheers' (< hakuna matata) \\ 'white person' (<mzungu) \\ 'beer' (<pombe)
}

Unlike the other forms presented above, these examples are characteristic of reverse transition, i.e. of travel back to the airport from the resort. They might serve apotropaic purposes, such as shouting at the foreign and Other in order to chase them away. Once the speakers leave the bus and 
enter into another form of transit - airport transit - they change their speech register again, often interrupted by bouts of silence.

In the poem 'Sonnet of Exemplary Sentences from the Chapter Pertaining to the Nature of Pronouns in Émile Benveniste's Problems in General Linguistics (Paris, 1966)', Anne Carson mentions eating a particular fish not necessarily involves knowing its name.

\section{Roadside Narratives}

18 April 2018 - Likoni - Tiwi - Ukunda: Three locations in Kenya. These toponyms are normally found on matatus, the small buses that run between these places, and serve as directional markers. They demarcate places along a road in Kenya that doesn't naturally meander, but rather follows the coastline rectilinearly from Mombasa southwards, having probably destroyed natural habitats during its construction. Rectilinearity is a shocking and destructive term in regard to nature and humans. It exposes the vulnerability of togetherness by presupposing that if someone or something is in the direct way between two places, it will be cut apart. For this particular road, this scenario probably took place when the road was constructed, but since then, people have integrated the road into their daily lives and their neighbourhoods. The land on both sides of the road belongs to the government, and people living in the area are supposed to know the width of the road reserve. The Standard, a Kenyan newspaper, writes in 2010 that: 'the common road sizes (road carriageway plus road reserve) are nine meters, $12 \mathrm{~m}, 15 \mathrm{~m}, 18 \mathrm{~m}, 25 \mathrm{~m}$ and $30 \mathrm{~m}$ depending on the opinion of the physical planner and local authority's town planning department.' ${ }^{1}$ The varying distances illustrate the discretion of the government and the understandable lack of knowledge of the appropriate measures by the people living along the road. People have thus started to build houses or shops along the road, ignoring blueprints and rules concerning government land. What is a livelihood for many people is a thorn in the side of officials. For decades, people have been constructing their stalls along the road, depending on finding a good place in order to earn money.

On 18 April 2018, excavators and bulldozers dug a swath of destruction approximately $10 \mathrm{~km}$ along the highway on both sides. The owners had been informed three days in advance that they had to destroy their property themselves; otherwise they would be charged for the demolition. Therefore, the owners of a private school who had set up their sign where many other signs had been for years went and demolished it (Figure 5.1), while the neighbours watched them, hoping for the best and not thinking about demolishing their own livelihoods (Figures 5.2-5.7). 


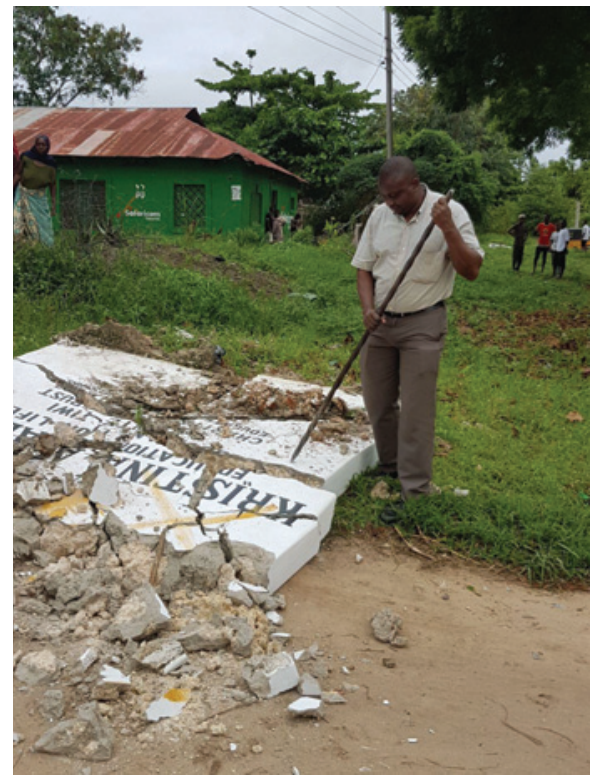

Figure 5.1 Owners of a school destroying their own road sign

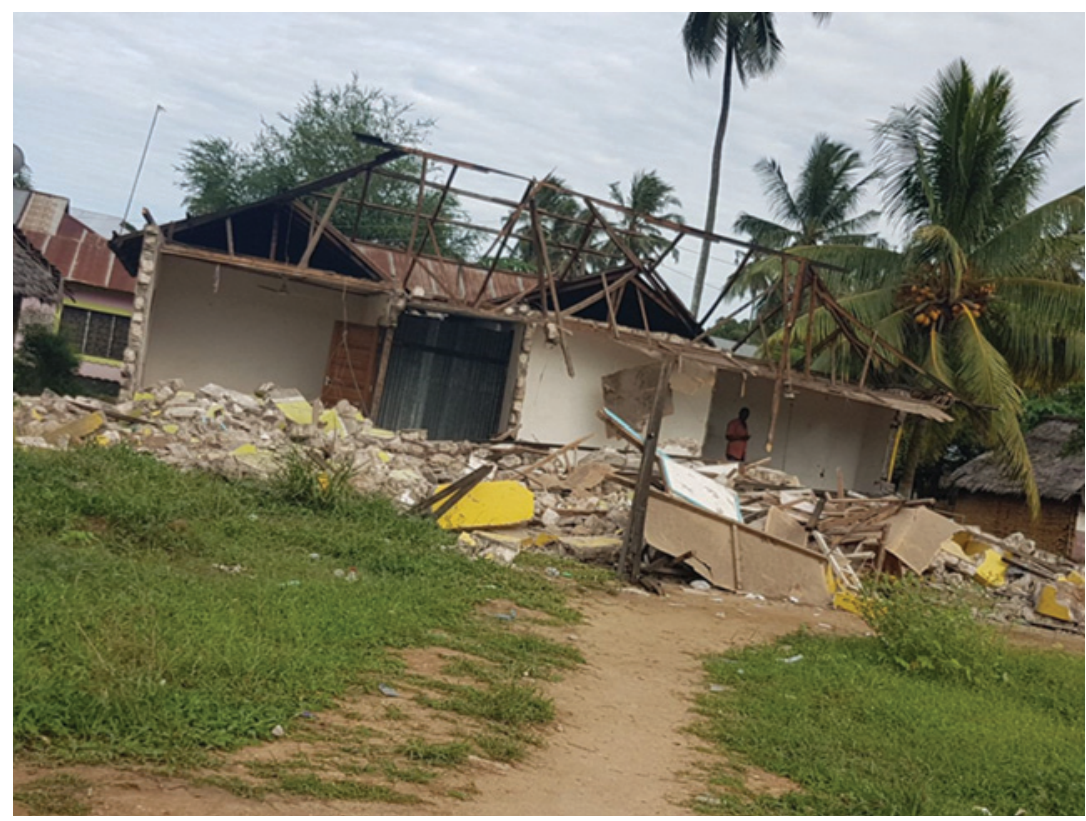

Figure 5.2 Remnants of a house partly built on governmental land 


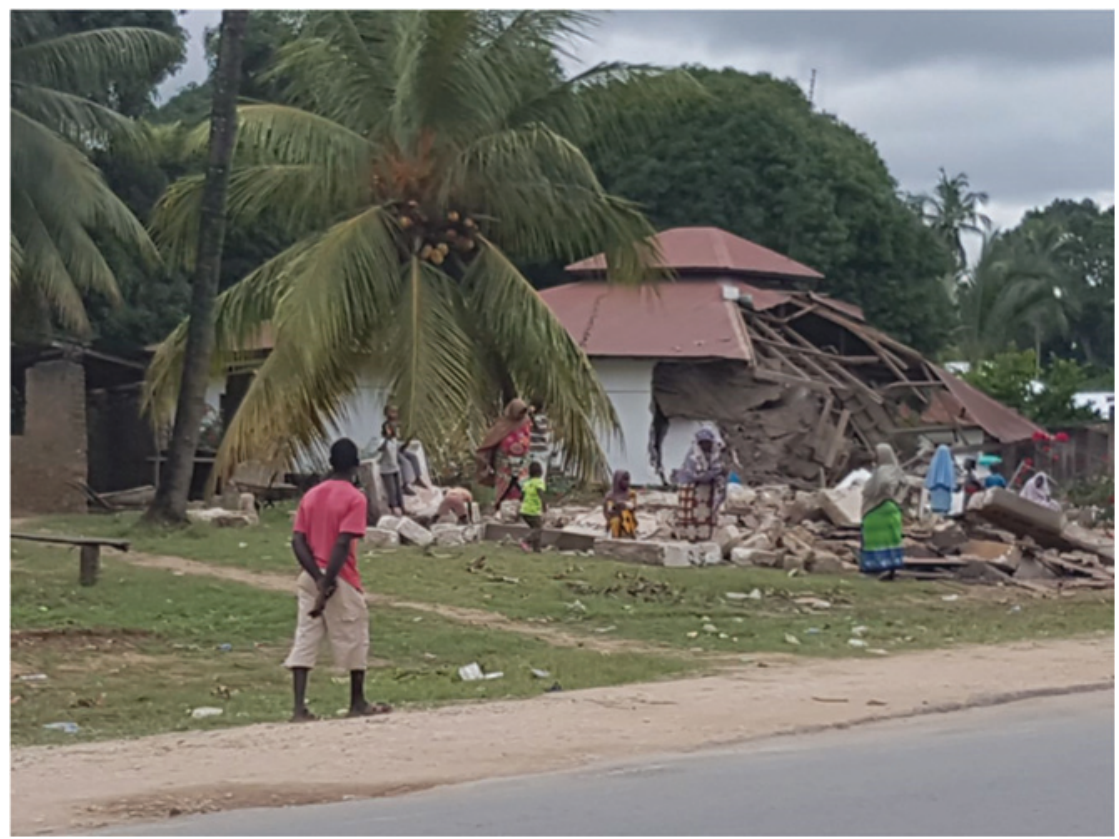

Figure 5.3 Remnants of another house partly built on governmental land

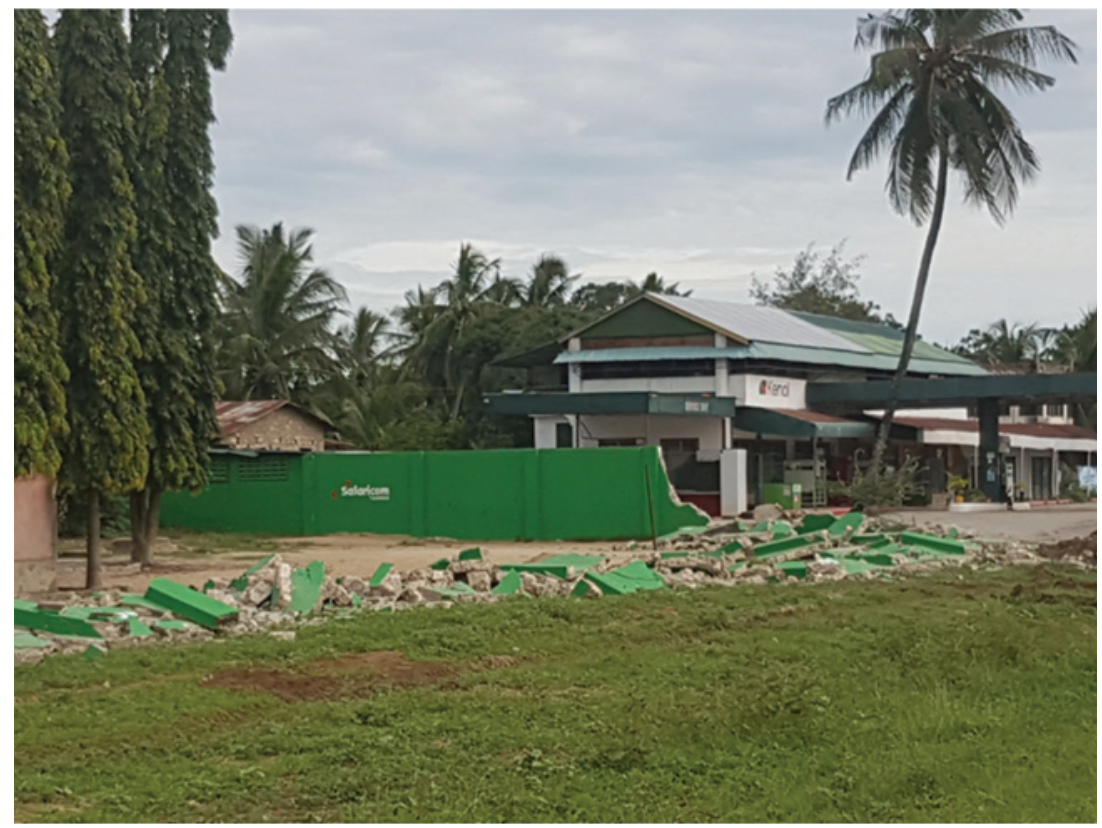

Figure 5.4 Demolished by bulldozers: the wall of a school in Tiwi 


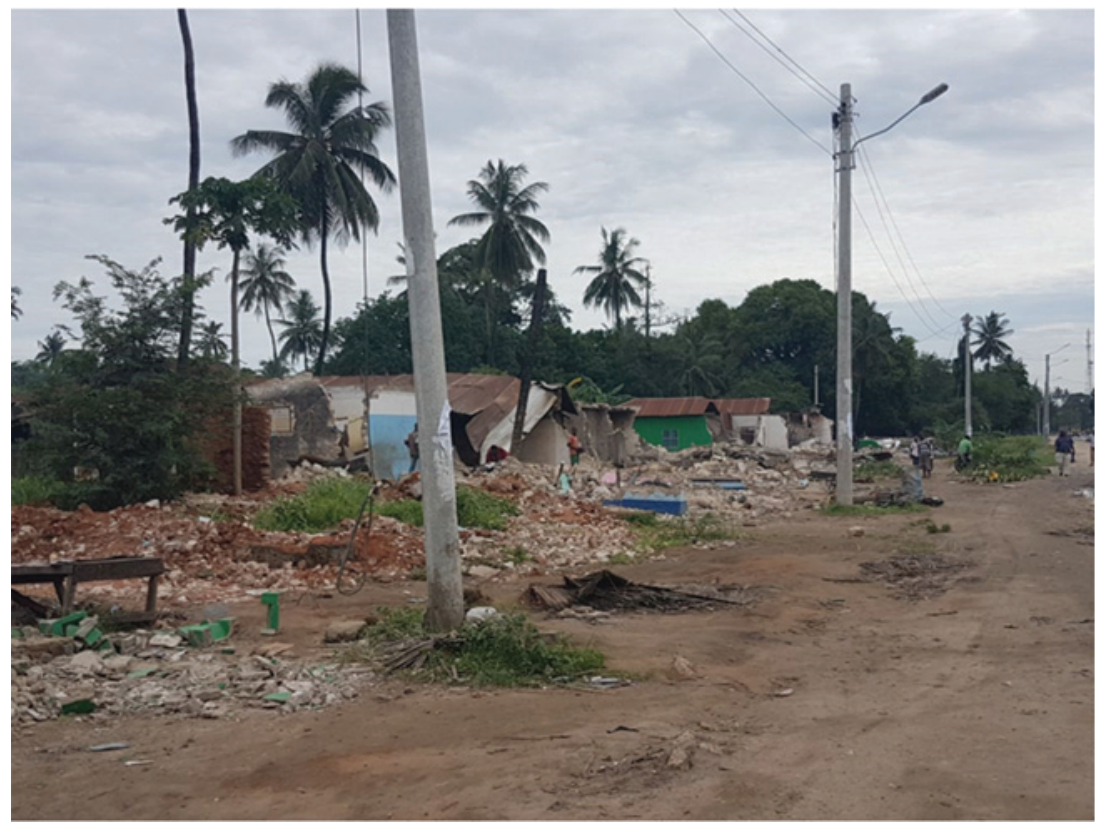

Figure 5.5 No houses left

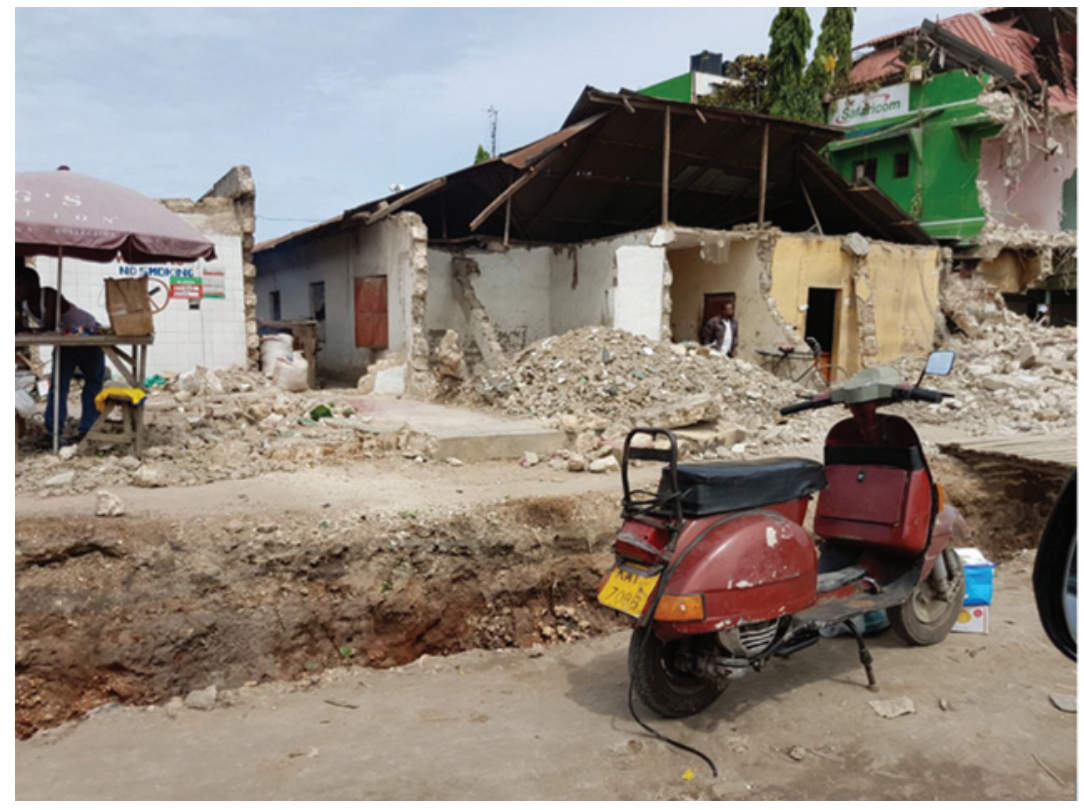

Figure 5.6 Demolition of homes 


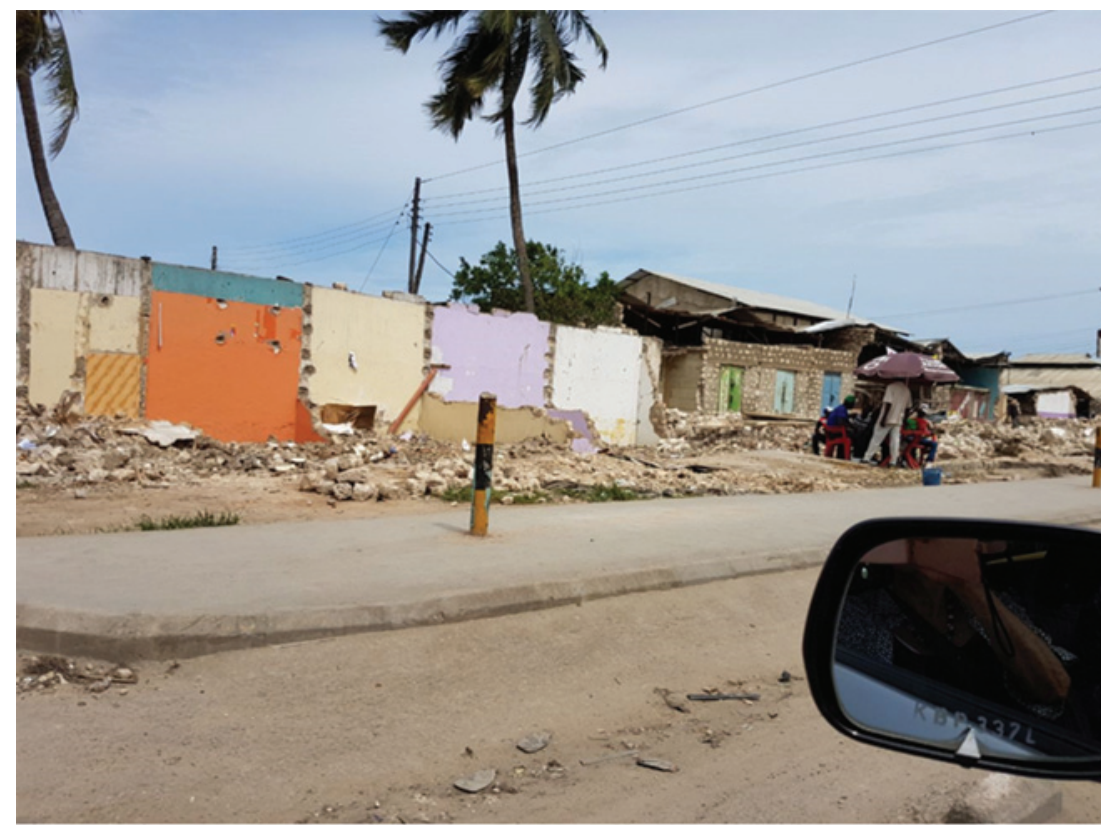

Figure 5.7 What is left: coloured walls of former happy homes

The Star describes the day of demolition as complete chaos:

Traders at Kongowea market incurred losses running into millions of shillings on Thursday after the highways authority demolished their stalls. Some of the business people at the market's Lights section broke into tears after their pleas to the Kenya National Highways Authority fell on deaf ears. This section of the market accommodates around 1,500 traders. The victims got to work early as 5 am hoping to earn their families some money. Hell broke loose at around $7.30 \mathrm{am}$ when a bulldozer's engine roared to life, flattening everything in front of it. ${ }^{2}$

The legislature clearly sits at the longer end of the lever and the ruination of families will soon be forgotten.

What follows are some photographs that record the ruination along a touristic road, the road from Mombasa to Ukunda, where thousands of people spend their holidays every year, passing along the road exactly four times during their stay: on their way from and to the airport and to and from a National Park (with the exception of those who visit the Masai Mara National Park, as they normally take a flight from Ukunda). Tourists are not informed about the topic of the road reserve demolition and watch the scenery without much emotion, albeit with astonishment (see Examples 3-4 above).

The roads are clean, clean and rectilinear, cutting through the private lives of individuals. One can see the inside of privacy, the painted walls as 
they shine in orange and purple, like posters without a message. The openly depicted intestines of privacy let curious others reflect about what has been there before, who has lived in there, who decided to paint a wall yellow. Perspectives vary in this scenario of ruination. Small-scale business along the road is destroyed, giving way to unproblematic transport, both national and international. We asked a man who has a security company in Diani, not far from this area, about the reason for the road demolition. He writes:

Regarding the road issue, it's been said many times that the roads infrastructure needs to be improved so that trade with our regional partners, within Africa who are landlocked can have their cargo delivered without much challenge as it is at the moment. The other reason is to improve on the flow of traffic as there are many cars in the country but the roads are still not big enough to accommodate all cars at the same time hence the usual traffic jams, so the only way was to have the roads expanded by using the road reserve and anyone on the reserve was removed by force as it's government land.

The demolitions were very necessary in the first place even without the expansion as the road reserve which is government land meant for road expansion had been given out illegally by corrupt officials who never thought that the government would catch up with them at one time. The other people who had their properties demolished were the ones who interfered with the riparian land. This is where our natural rivers used to flow but again the greedy and corrupt officials again sold this land that is close to the rivers and affected their motion or movement. The government has been demolishing most of these buildings and unfortunately the prestigious shopping malls have been caught up in this demolitions as some of them were on the riparian land.

Since the pictures were taken, not much has changed. People have collected their corral stones and stored them properly in order to be safe from theft. Nobody dares to start constructing again. Salespeople have taken up positions to sell their goods without a stall. A year and a half later, broken walls stand amidst lovely vegetation which slowly repossesses land. Other demolished buildings are freshly painted in turquoise, yellow and pink, as life goes on. There is no sign of road work, anywhere, which once was the reason why people were made homeless.

\section{Notes}

(1) See https://www.standardmedia.co.ke/business/article/2000023256/establishingyour-plot-boundaries (accessed 12 August 2020).

(2) See https://www.the-star.co.ke/news/2018/02/22/kongowea-traders-break-intotears-as-kenha-flattens-stalls_c1719106 (accessed 12 August 2020). 


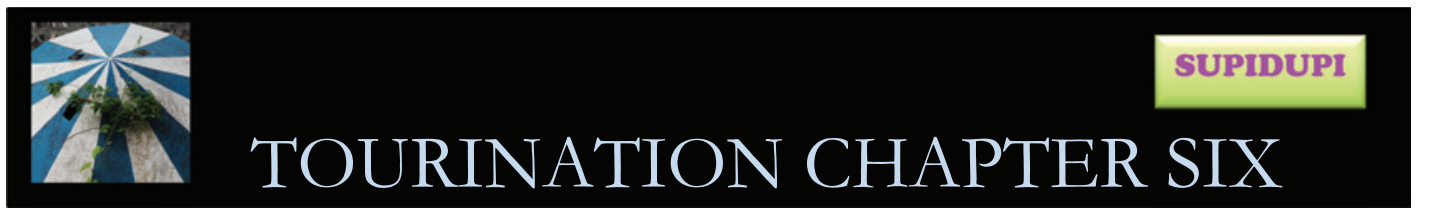

\section{RUINS ON THE BEACH}
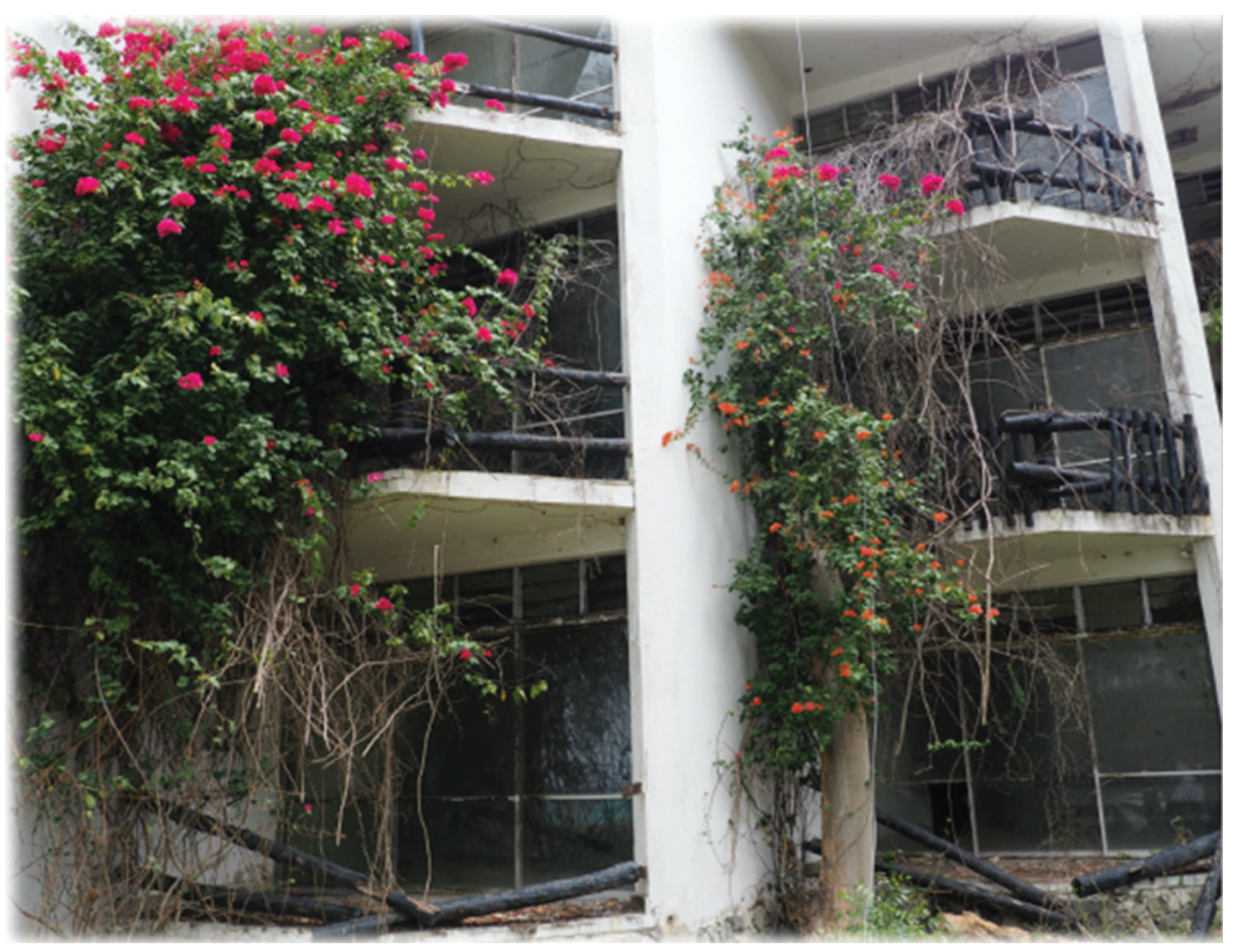

RUBBLE $\star$ DUST $\star$ DEBRIS $\star$ CORPSES $\star$ SHATTERED DREAMS $\star$ FAECES $\star$ TORN PAPERS $\star$ GARBAGE $\star \star \star \star \star$ 
